\title{
HUBUNGAN ANTARA KEBUTUHAN UNTUK SUKSES DAN KETEKUNAN BELAJAR MAHASISWA PENDIDIKAN PROFESI GURU TERINTEGRASI (PPGT) FKIP UNIB ANGKATAN 2012
}

\author{
Resnani \\ Pendidikan Guru Sekolah Dasar \\ Fakultas Keguruan dan Ilmu Pendidikan, Universitas Bengkulu \\ Email: resnani12@gmail.com
}

\begin{abstract}
Abstrak
Tujuan penelitian ini adalah untuk mengetahui tingkat kebutuhan untuk sukses, tingkat ketekunan belajar, dan untuk mengetahui kolerasi antara tingkat kebutuhanuntuk sukses dan tingkat ketekunan belajar mahasiswa PPGT angkatan 2012. Metode penelitian yang digunakan adalah teknik analisis kolerasi product moment. Populasi penelitian adalah seluruh mahasiswa PPGT angkatan 2012. Sampel penelitian adalah sampel penuh yaitu semua populasi yang berjumlah 34 siswa dijadikan sampel penelitian. Hasil penelitian menunjukkan bahwa tingkat kebutuhan untuk sukses termasuk kategori sedang dengan angka rata-rata46,6. Tingkat ketekunan belajar termasuk kategori sedang dengan angka rata-rata 43.9. Hal ini menunjukkan bahwa terdapat korelasi antara kebutuhan untuk sukses dan ketekunan belajar mahasiswa PPGTangkatan 2012 dengan koefisien korelasi sebesar 0.547
\end{abstract}

Kata kunci : kebutuhan untuk sukses, ketekunan belajar, mahasiswa.

\section{PENDAHULUAN}

Belajar adalah suatu proses perubahan tingkah laku sebagai hasil interaksi individu dengan lingkungan. Sebagai suatu proses,berarti bahwa berhasil tidaknya seorang dalam belajar akan dipengaruhi oleh banyak faktor. Secara garis besar, faktor yang dapat mempengaruhi hasil belajar atau prestasi seseorang dikelompokkan dalam dua bagian yakni, faktor intern dan faktor ekstern. Faktor intern adalah segala faktor yang bersumber dari dalam diri pribadi orang yang belajar, seperti IQ, bakat, motif, sikap, perhatian, ketekunan, motivasi berprestasi dan sebagainya. Sedangkan faktor ekstern adalahsegala faktor yang bersumber dari luar diri pribadi orang yang belajar, seperti lingkungan keluarga, lingkungan sekolah, lingkungan masyarakat, kurikulum, tenaga pengajar, metode pembelajaran, sarana, prasarana belajar dan sebagainya.

Dari berbagai faktor tersebut diatas, faktor motivasi berprestasi mempunyai pengaruh penting bagi keberhasilan seseorang. Sehubungan dengan ini,Cumbo dalam Elida (2004)menyatakan bahwa betapa pun baiknya potensi anak yang meliputi kemampuan intelektual atau bakat, baiknya materi yang akan diajarkan, lengkapnya sarana belajar, namun siswa tidak bermotivasi dalam belajar, maka proses belajar tidak akan berlangsung dengan optimal. Ini berarti, motivasi belajar merupakan daya penggerak bagi seseorang untuk belajar untuk melakukan aktivitas belajar, termasuk bagi mahasiswa PPGTangkatan 2012.

Menurut Taufik (2011), salah satu faktor penting dan yang menjadi daya penggerak bagi seseorang untuk belajar adalah keinginannya untuk berprestasi sebagai upayamemenuhi kebutuhan untuk sukses dan kebutuhan untuk menjauhi kegagalan dalam belajar. Dengan demikian, jika seseorang memiliki kebutuhan sukses yang tinggi, maka ia akan bekerja keras dan tekun dalam belajar. Seseorang akan melakukan sesuatu perbuatan dimulai karena dirasakan adanya suatu kebutuhan. 
Sehubungan dengan ini,Sarlito (2013) mengemukakan bahwa perbuatan dimulai dengan adanya lapar atau takut. Keadaan tidak seimbang ini tidak menyenangkan bagi individu yang bersangkutan, sehingga timbul kebutuhan untuk meniadakan ketidakseimbangan itu, misalnya mencari makanan atau mencari perlindungan.

Kebutuhan inilah yang akan menimbulkan dorongan atau motif untuk berbuat. Dari pendapat ini terkandung makna bahwa kebutuhan itu merupakan kekurangan yang memerlukan pemenuhan. Sehubungan dengan ini, Partini (2008)menyatakan bahwa kebutuhan (need) dapat dipandang sebagai kekurangan adanya sesuatu, dan ini menuntut segera pemenuhannya, untuk segera mendapatkan keseimbangan. Situasi kekurangan ini berfungsi sebagai suatu kekuatan,dorongan atau alasan yang menyebabkan seseorang bertindak untuk memenuhi kebutuhan.

Apabila teori diatas dikaitkan dengan studi mahasiswa, maka kesuksesan dalam studi dapat dipandang sebagai sesuatu kebutuhan. Dengan merasakan kesuksesan dalam studi sebagai suatu kebutuhan, akan mengarahkan aktivitas mahasiswa yang bersangkutan untuk meraih kesuksesan tersebut. Dalam rangka meraih kesuksesan itu, tentu tidak ada cara lain kecuali belajar dengan tekun. Dalam kaitannya dengan ketekunan belajar, kebutuhan untuk suskses dapat dipandang sebagai daya penggerak bagi seseorang mahasiswa sehingga ia melakukan aktivitas belajar yaitu belajar dengan tekun. Oleh karena itu, kebutuhan untuk sukses dapat pula dikaitkan dengan motivasi belajar. Kebutuhan untuk sukses adalah indentik dengan kebutuhan berperestasi.

Setiap manusia berbeda kebutuhan berprestasi. Ada mahasiswa yang memiliki kebutuhan berprestasi tinggi dan ada pula yang rendah. Mahasiswa memiliki kebutuhan berprestasi tinggi kalau keinginan untuk sukses benar-benar berasal dari dalam diri sendiri. Mahasiswa yang memiliki kebutuhan berprestasi rendah cenderung takut gagal dan kurang mau menanggung resiko dalam mencapai prestasi yang lebih tinggi (Elida, 2004).
Lebih lanjut Elida (2004) mengemukakan bahwa kebutuhan untuk berprestasi dapat menjadi suatu faktor yang bermotivasi dalam belajar. Atas pendapat ini dapat dikatakan bahwa mahasiswa yang memiliki kebutuhan untuk sukses tinggi ada kecenderungan akan melakukan aktivitas dengan penuh ketekunan. Dengan kata lain, mahasiswa yang memiliki tinggkat ketekunan yang tinggi merupakan salah satu pertanda bahwa ia tahu mereka memilki kebutuhan untuk sukses yang tinggi.

Ada beberapa indikator yang mencerminkan mahasiswa memilki kebutuhan untuk sukses yang tinggi, antara lain: tidak cepat berputus asa bila menemukan kesulitan dalam belajar; tidak cepat puas terhadap prestasi yang dicapai; terbuka dalam menerima kritikan; selalu berkeinginan untuk meningkatkan hasil belajar; berkeinginan untuk mencapai hasil belajar yang terbaik; tidak cepat merasa jenuh/bosan; sangat berkeinginan menyelidiki hal-hal yang baru, dan sangat berkeinginan menegakkan disiplin dan lain sebagainya (Elida, 2004).

Berdasarkan uraian diatas, maka tujuan penelitian ini dapat dirumuskan sebagai berikut: (1) untuk mengetahui tingkat kebutuhan untuk sukses mahasiswa PPGTangkatan2012; (2) untuk mengetahui tingkat ketekunan belajr mahasiswa PPGTangkatan 2012; (3) untuk mengetahui tingkat hubungan (korelasi) antara tingkat kebutuhan untuk sukses dan tingkat ketekunan belajar mahasiswa PPGT angkatan 2012.

\section{METODE}

Jenis penelitian ini adalah penelitian kuantitatif dengan metode korelasi. Metode ini digunakan untuk melihat hubungan antarvariabel dalam penelitian. Sehubungan dengan ini, Darmadi (2011) menyatakan bahwa metode korelasi betujuan untuk menentukan ada tidaknya hubungan antara variabel dan seberapa besar hubungan yang ada antara dua variabel atau lebih. Untuk menganalis data tentang tingkat kebutuhan untuk sukses dan tingkat ketekunan belajar digunakan teknik analisis angka rata-rata. Untuk menganalisis hubungan antara kebutuhan untuk sukses dan tingkat ketekunan belajar 
mahasiswa digunakan teknik korelasi product moment.

Populasi dalam penelitian ini adalah seluruh mahasiswa PPGTangkatan 2012 yang bejumlah 34 mahasiswa. Sampel penelitian diambil sampel penuh yakni semua populasi dijadikan sampel penelitian. Hal ini sejalan dengan pendapat Arikunto (2006) yang menyatakan bahwa untuk sekedar ancer-ancer dalam pengambilan sampel apabila sampelnya kurang dari 100, lebih baik diambil semua sehingga penelitiannya merupakan penelitian populasi. Hal ini diperkuat dengan pendapat Darmadi (2011) yang menyatakan bahwa jumlah sampel terkecil yang dapat diterima pada riset korelasi adalah 30 subjek. Pengumpulan data adalah melalui angket, baik data mengenai kebutuhan untuk sukses maupun data tentang ketekunan belajar. Jadi, sampel dalam penelitian ini adalah sampel penuh yang berjumlah 34 orang mahasiswa.

\section{HASIL DAN PEMBAHASAN}

Analisis data dilakukan untuk menjawab tiga permasalahan penelitian, yakni : (1) data tingkat kebutuhan untuk sukses, (2) data tingkat ketekunan belajar, dan (3) data tentang hubungan antara tingkat kebutuhan untuk sukses dan tingkat ketekunan belajar.Berdasarkan hasil perhitungan, diperoleh hasil sebagai berikut ini. (1) Dari 34 mahasiswa yang diberi angket tentang kebutuhan untuk sukses diperoleh sekor sebesar 1.428. Setelah dicari rata-rata diperoleh angka rata-rata sebesar 46.06,angka tersebut termasuk pada kategori sedang. (2) Dari 34 mahasiswa yang diberi angket tentang ketekunan belajar diperoleh jumlah skor sebesar 1.362. Setelah dicari rata-rata diperoleh angka rata-rata sebesar 43.9, angka tersebut termasuk kategorisedang. (3) Dengan menggunakan teknik analisis korelasi product moment dengan rumus angka kasar, diperoleh thitung sebesar 0.547. Setelah dibanding dengan harga keritik korelasi (rt) dengan $\mathrm{n}=34$ pada taraf signifikan 0.05 sebesar 0.355 dan pada taraf signifikan 0.01 sebesar 0.456 , ternyata thitung sebesar 0.547 tersebut lebih besar. Hal ini menunjukkan bahwaterdapathubungan (korelasi) positif antara kebutuhan untuk sukses dengan ketekunan belajar mahasiswa PPGTangkatan 2012.

Penelitian ini membuktikan bahwa tingkat kebutuhan untuk sukses dan tingkat ketekunan mahasiswa PPGTangkatan 2012 adalah sedang dengan angka rata-rata masing-masing sebesar 46.06 dan 43.9. Sungguh pun angka rata-rata tingkat kebutuhan untuk sukses sebesar 46.06 dan angka ketekunan belajar 43.9 termasuk katagori sedang. Akan tetapi, masih relatif jauh dari standar pada maksimal pada kategori sedang yaitu 54.

Kebutuhan untuk sukses dapat dipandang sebagai salah satu faktor yang dapat menguatkan motivasi belajar seorang mahasiswa. Selajutnya motivasi belajar yang kuat akan menjadi daya dorong tersendiri bagi seorang mahasiswa untuk melakukan kegiatan belajar secara tekun, yang dalam hal ini disebut dengan ketekunan belajar. Penelitian ini juga membuktikan bahwa terdapat korelasi antara kebutuhan untuk suskses dan tingkat ketekunan belajar mahasiswa PPGTangkatan 2012 dengan koefisien korelasi sebesar 0.547. Atas dasar ini dapat dikatakan bahwa seseorang mahasiswa memiliki tingkat kebutuhan sukses yang tinggi, ada kecenderungan untuk menunjukkan tingkat ketekunan belajar yang tinggi pula.

Oleh karena kebutuhan untuk sukses dipandang sebagai motivasi untuk belajar, maka sangat diperluhkan adanya upaya untuk membangkitkan motivasi belajar. Elida (2004) menyatakan bahwa adanya beberapa cara untuk membangkitkan motivasi belajar, diantaranya adalah memberikan penghargaan, persaingan dan kompetisi, hadiah dan hukuman, serta pemberian tentang kemajuan belajar.Menurut Cumbo dalamElida (2004) penghargaan sangat efektif untuk memberikan motivasi dalam memberikan tugas, baik tugas-tugas yang dikerjakan dengan segera maupun tugas-tugas yang berlangsung terus menerus. Teori ini juga diperluhkan bagi mahasiswa.

Memupuk persaingan atau kompetisi antaramahasiswa lebih banyak berpengaruh terhadap keperibadian mahasiswa. Akan lebih 
baik jika dibentuk persaingan antardiri sendiri. Hal ini dapat dilakukan dengan memberikan kesempatan kepada para mahasiswa untuk mengenal kemajuan-kemajuan yang telah dicapai sebelumnya dan apa yang dapat dicapai pada waktu berikutnya. Selajutnya, hadiah sebagai upaya memotivasi mahsiswa dapat menjadi penguat tingkah-laku mahasiswa. Sedangkan hukuman banyak memberi pengaruh psikologis yang negatif dibandingkan dengan motivasiyang ditimbulkannya. William dalamElida (2004) menyatakan memang akan ada kemungkinan hukuman meningkatkan proses belajar siswa, namun siswa akan berhenti belajar jika hukuman ditiadakan.

Crow dan Smit dalamElida (2004) mengemukakan bahwa akan timbul kegembiraan dan keinginan untuk meningkat kegiatan belajar dalam diri siswa, jika ia mengetahui kemajuan yang telah dicapainya. Berbagai eksperimen yang dilakukan menyokong keyakinan diatas, bahwa seiring dengan diketahuinya kemajuan nyata yang telah diperoleh siswa, maka usaha berikutnya akan berlangsung.

Berdasarkan uraian diatas, dapat dikemukakan bahwa di dalam membangun motivasi secara efektif yang penting dilakukan adalah mempelajari kebutuhan mahasiswa secara individu, sedalam dan seluas mungkin sehingga tenaga pengajar dapat menyusun strategi pembelajaran yang sesuai dengan kebutuhan mahasiswa. Dosen perluh mengetahui secara pasti berapa dan siapa yang tinggi, sedang dan rendah.

Selain cara-cara yang telah dikemukakan di atas, ada beberapa cara lain yang dapat dilakukan oleh dosen dalam rangka menumbuhkembangkan kebutuhan untuk sukses. Cara tersebut antara lain adalah (1) mewujudkan prosedur pembelajaran yang melibatkan mahasiswa secara aktif, seperti diskusi, tanya jawab, pemberian tugas dan sebagainya. (b) Mengorganisasikan materi perkuliahan sedemikian rupa sehingga mahasiswa mudah dan senang mempelajarinya. (3) memilih dan menggunakan media pembelajaran yang efektif untuk meningkatkan motivasi belajar para mahasiswa. (4) Memanfaatkan evaluasi sebagai umpan balik bagi usaha peningkatan hasil belajar mahasiswa selajutnya. Untuk keprluan ini maka evaluasi harus dilakukan secara terencana untuk mengetahui kemampuan belajar mahasiswa.

\section{SIMPULAN}

Hasil penelitian menunjukkan bahwa kebutuhan untuk sukses dan tingkat ketekunan belajar mahasiswa PPGTAngkatan 2012 termasuk kategori sedang dengan angka rata-rata masing-masing 46.06 dan 43.9. Selajutnya dapat berkorelasi positif antara kebutuhan untuk sukses dan tingkat ketekunan belajar mahasiswa PPGTangkatan 2012 dengan koefisien korelasi sebesar 0.547. oleh karena kebutuhan untuk sukses sebagai motivasi belajar yang mempunyai hubungan yang berati (signifikan) dengan ketekuna belajar mahasiswa, maka sangat diperluhkan adanya upaya oleh dosen untuk menumbuhkembengkan atau membangkitkan motivasi beljar mahasiswa.

Berdasarkan hasil penelitian ini, maka disarankan pada para pengajar (dosen) sebagai berikut: (1) dosen hendaknya dapat mengenal lebih dalam tentang krakteristik mahasiswa secara individual untuk dijadikan bahan pertimbangan dalam menyusun strategi pembelajaran; (2) dosen dalam proses pembelajaran hendaknya dapat senantiasa meningkatkan keterlibatan mahasiswa. Hal ini dapat ditempuh dengan menggunakan metode pembelajaran yang dianggap efektif dalam melibatkan para mahasiswa, seperti diskusi, tanya jawab, pemberian tugas; (3) dosen hendaknya menciptakan kondisi lingkungan belajar yang menyenangkan sehingga membangkitkankegairahan mahasiswa untuk melakukan kegiatan belajar secara tekun, misalnya dengan cara memberikan kesempatan yang luas kepada mahasiswa untuk bertanya atau mengemukakan pendapat; (4) kepada mahasiswa yang mencapai prestasi yang belajar yang tinggi, hendaknya diberikan penghargaan. Penghargaan dapat bersifat verbal maupun material.

\section{DAPTAR PUSTAKA}


Hubungan Antara Kebutuhan Untuk Sukses Dan Ketekunan Belajar Mahasiswa Pendidikan Profesi

Guru Terintegrasi (PPGT) FKIP UNIB Angkatan 2012

Arikunto, Suharsimi. 2010. Dasar-dasar Evaluasi Pendidikan. Jakarta: Bumi Aksara.

Darmadi, Hamid. 2011. Metode Penelitian Pendidikan. Bandung: Alfabeta.

Elida Prayitno. 2004. Motivasi dalam Belajar. Jakrta: Depdikbud, Dirjen Dikti, Proyek Pengembengan LPTK.
Sarlito, Wirawan, Sarwono. 1913. Teori-teori Psikologi Sosial. Jakarta: CV. Rajawali.

Taufik, Agus, dkk. 2011. Pendidikan Anak di $S D$. Jakarta: Universitas Terbuka.

Partini Suardiman. 2008. Psikologi Pendidikan. Yogyakarta: FIP-IKIP. 